\title{
The language of justice : when the colonial past is invited into the courtroom
}

Natalie Tarr

\section{(2) OpenEdition \\ 1 Journals}

Electronic version

URL: http://journals.openedition.org/edl/2499

DOI: 10.4000/edl.2499

ISSN: 2296-5084

Publisher

Université de Lausanne

\section{Printed version}

Date of publication: 15 December 2017

Number of pages: 155-172

ISBN: 978-2-940331-66-6

ISSN: 0014-2026

Electronic reference

Natalie Tarr, "The language of justice: when the colonial past is invited into the courtroom », Etudes de lettres [Online], 3-4 | 2017, Online since 15 December 2019, connection on 17 December 2020. URL: http://journals.openedition.org/edl/2499; DOI : https://doi.org/10.4000/edl.2499 


\section{THE LANGUAGE OF JUSTICE: WHEN THE COLONIAL PAST IS INVITED INTO THE COURTROOM}

Dans les tribunaux au Burkina Faso seule la langue française est admise, tel un héritage du colonialisme. Comme les justiciables, dans leur grande majorité, ne parlent pas cette langue officielle, ils ont besoin d'un interprète. L'interprétariat a une longue histoire en Afrique, mais le rôle de l'interprète n'a jamais été aussi mal défini qu'aujourd'hui. L'emploi du français, qui «s'invite» dans les tribunaux du Burkina, est analysé ici comme une continuation du passé colonial et le retour étonnant d'une célèbre figure littéraire.

Être la bouche de quelqu'un, c'est être son auxiliaire le plus précieux et le plus indispensable ${ }^{1}$.

[...] [T]ranslation is a process, never a completed accomplishment and it may [...] fail ${ }^{2}$.

\section{A day in court - Prologue}

The courtroom at the tribunal de grande instance in Bobo-Dioulasso, Burkina Faso, looks like a stage. The members of the court perform a well-rehearsed choreography here at the criminal court. This feeling arises because the procedure is exactly the same every time I come to

I. A. Hampâté Bâ, L'étrange destin de Wangrin ou les roueries d'un interprète africain, p. 370, endnote 81 .

2. M. Callon, "Some elements of a sociology of translation", p. 196. 
observe a day of trials. First, a clerk moves busily back and forth between offices and the courtroom, bringing in an impressive pile of files - les dossiers - and a huge, black ledger for today's court session. He places the ledger on the prosecutor's desk. Later I realize that this is the court's calendar, where prosecutors note when whose trial will take place and what the accusation is. Once this task has been accomplished, the clerk turns on the air conditioner and fans, pushes chairs into position and reprimands those individuals in the audience, who seem to not follow the etiquette as he sees it. With a snap of his fingers and a swiping hand gesture he orders one man to take off his hat. Satisfied, he then checks if the five members of the court - three judges, one prosecutor and one scribe - are ready to enter the courtroom. If they are, he can finally ring the bell and loudly announce La cour! which is the sign for everybody to get up. Then the door opens and the toga-clad, serious looking members of the court enter, moving towards their designated seats and sitting down. Now the clerk transforms into the court interpreter, in turn taking his designated seat between the judges' and the prosecutor's desks.

Everybody in the salle d'audience only sits back down when the presiding judge has opened the proceedings, giving us all permission to do so. In this play, the audience is made up of family members and friends of defendants, interested lay people or the curious. They have arrived punctually, filling the benches to the last space available. I, too, sit down in my designated chair, between the bar where the defendants stand and the bench on which witnesses and victims sit. I have a good view of the stage and the actors, the court members. The audience behind me is attentive, not always holding back comments or audibly suffering along with the defendant - or ridiculing him together with a judge or prosecutor when fancy takes them. A frivolous crowd. The judge bangs his pen on the desk, ordering the crowd to be quiet or they will be removed: Ceux qui veulent bavarder peuvent sortir! The judge tells the audience to retenir leurs ardeurs, to keep their opinion to themselves or they will end up on the same bench as the prisoners. It is quite clear who is in control of the proceedings. 


\section{Introduction}

Interaction in the courtroom is thus highly prescribed: the sitting order is always the same and the court sits, defendants stand. Communication as well follows strict guidelines: who may speak first, who may speak when and to whom in which order and in which language follow specific rules. This is hardly a new observation - participating in the courtroom space resembles a theatrical production in other places as well. But in Burkina Faso not all actors know their position ${ }^{3}$ in the play. In other words, this particular play is staged without the defendants having had access to their script. They do not know the protocol and many of them do not speak the language used on the courtroom stage - French. Article 35 of the constitution of Burkina Faso states that: "La langue officielle est le français. La loi fixe les modalités de promotion et d'officialisation des langues nationales." In spite of the country being highly plurilingual - about seventy languages are spoken on its territory - only French enjoys being specifically mentioned, the other languages are lumped together under the designation national languages. Judges take this to mean that only French can be used in the courtroom space and during a trial.

Here, I will look more closely at the role the French language plays in Burkina Faso's justice system today, particularly at the impact French has on court proceedings, such as on the administration of justice. My research focuses on criminal courts because here the International Covenant on Civil and Political Rights "specifically guarantees one's right to the free assistance of an interpreter if one does not understand or speak the language used in court" "4. Burkina Faso has ratified this law in $1999^{5}$. Indeed, in Burkina Faso, the vast majority of defendants does not speak the language used in court.

Historically interpreters - also called linguists - have always occupied prominent positions in Africa, assisting in the communication between sovereigns and their people. Later, interpreters became important

3. The concept of positioning comes from social psychology and was developed by B. Davies and R. Harré in "Positioning: the discursive production of selves". Positioning is a discursive, interactional practice, which means people are defined/ positioned or position themselves conversationally.

4. H. Mikkelsen, R. Jourdenais, The Routledge handbook of interpreting, p. 186.

5. <http://indicators.ohchr.org>, accessed 18 May 2016. 
intermediaries in the administration of colonial rule. And this is the historical period I will focus on: from the early 1800s onwards, when the French language was imported, promoted and eventually institutionalized in West Africa. I will show that, apart from the languages used, the court interpreter is more similar to the king's linguist of old than to his chronologically closer counterpart during colonial times. The colonial past is indeed very present in the courtroom of the 21 st century with the use and imposition of the French language. One question I will attempt to answer is who keeps sending out invitations - who makes it possible for the colonial past to be present in today's courtroom. Before moving on to the person and itinerary of the interpreter across time, lets take a look at the French justice system in Burkina Faso and how it was translated into French West African reality and fiction, because African francophone literature has largely integrated this character, the trickster who knows how to take advantage of the two worlds he belongs to.

\section{Colonial justice - a walk with Wangrin, Samba Diallo and Meka}

During colonial times, French bureaucrats set about educating specifically trained interpreters. Ever since the early 1800 s, when the first European model schools were opened in French West Africa ${ }^{6}$, the French language has been aggressively promoted and positioned as the sole vector capable of transporting knowledge ${ }^{7}$. African languages and modes of learning, on the other hand, have been and continue to be systematically depreciated and marginalized. This ideology of linguistic hierarchization limited African languages in their functionality. In this way, the French redefined what being educated means - first as colonial administrators, later through neocolonial institutions such as la Francophonie and always through the school system and the French

6. The term French West Africa (and its French equivalent Afrique occidentale française) are colonial constructs. I am adopting this designation in order to create a category with a sociolinguistic aspect. We are only concerned with countries in West Africa, which had been colonized by the French.

7. J. Riesz, Französisch in Afrika, p. 3 ff.; N. Tarr, "Le message choisit la langue". 
language ${ }^{8}$. In L'aventure ambiguë, la Grande Royale expresses her feelings towards the new school like this:

J'ai fait une chose qui ne nous plait pas, et qui n'est pas dans nos coutumes. J'ai demandé aux femmes de venir aujourd'hui à cette rencontre. Nous autres Diallobé, nous détestons cela, et à juste titre, car nous pensons que la femme doit rester au foyer. Mais de plus en plus, nous aurons à faire des choses que nous détestons, et qui ne sont pas dans nos coutumes. C'est pour vous exhorter à faire une des ces choses que j'ai demandé de vous rencontrer aujourd'hui. Je viens vous dire ceci: moi, Grande Royale, je n'aime pas l'école étrangère. Je la déteste. Mon avis est qu'il faut y envoyer nos enfants cependant?

This strategy, made up of both renunciation and adaptation, makes a new historical, social and cultural phase visible in fiction. Maybe the government of Burkina Faso, following this same strategy, has adopted this colonial educative system unchanged with independence in 1960 and continues until today to (largely) use the same methods and didactics ${ }^{10}$.

The French have thus educated and promoted a class of men ${ }^{11}$, whom they formed specifically to further their project of conquest. Historically the interpreter was the go-between, the mediator or facilitator, making communication between the (white, French) colonial administration and the local population possible. The interpreter in Le vieux nègre et la médaille understands and does his job like this:

Le grand Chef dit qu'il est très content de se trouver parmi vous, qu'il dit merci pour le bon accueil que vous lui avez fait. Puis il a parlé de la guerre que vous avez faite ensemble contre les autres Blancs de chez

8. L.-J. Calvet, Histoire du français en Afrique; C. Canut, Le spectre identitaire, G. O. Midiohouan, "Portée idéologique et fondements politiques de la francophonie (vue d'Afrique)".

9. Ch. A. Kane, L'aventure ambiguë, p. 56.

Io. M. Mayrhofer-Deák, Sprache macht Schule; M. Mayrhofer-Deák, Der imperiale Mensch; N. Tarr, "Le message choisit la langue".

II. There are some few women who figure prominently in the literature and who acted during the early days of occupation (B. N. Lawrance, E. L. Osborn, R. L. Roberts Intermediaries, interpreters, and clerks, p. 26 sq.), but they will not be discussed here. 
lui... et il a terminé en disant que nous sommes plus que ses amis, nous sommes comme des frères, quelque chose comme cela... ${ }^{12}$

This interpreter represents the figure of the colonial go-between nicely by translating in summary what he thought was the essence of the message to be transmitted. This alteration of the original message would have been unthinkable to the king's linguist, the griot of old ${ }^{13}$. Let me explain.

Interpretation has always been part of everyday life in African societies. It was not the French who introduced the profession. The king had always talked to his people by way of his official translator or linguist, called griot in French (in the Mande language continuum they are called djeli). He spoke the language of the populace, but by virtue of his position as sovereign, the king could not address his people directly. The griot-linguist was responsible for embellishing the king's words, making them understandable, acceptable or even succulent to the immediate state of the populace's palate. But never was he to alter the meaning the king wanted to transmit to his people.

In 1855, the école des fils de chef or école des otages opened in SaintLouis-du-Sénégal, producing district chiefs (chef de canton), colonial clerks and interpreters to better further the French colonial project, which we can discover in Cheick Amidou Kane's novel, L'aventure ambiguë, first printed in 1961 :

On commença dans le continent noir, à comprendre que [la] puissance [des français] véritable résidait, non point dans les canons du premier matin, mais dans ce qui suivait ces canons. Ainsi, derrière les cannonières, le clair regard de la Grande Royale des Diallobé avait vu l'école nouvelle. L'école nouvelle participait de la nature du canon et de l'aimant à la fois. Du canon, elle tient son efficacité d'arme combattante. Mieux que le canon, elle pérennise la conquête. Le canon contraint les corps, l'école fascine les âmes ${ }^{14}$.

Interpreters could thus rely on a double education: they were educated in the French colonial school and in the African society they came

I2. F. Oyono, Le vieux nègre et la médaille, p. 118.

13. P. Bandia, "Esquisse d'une histoire de la traduction en Afrique".

I4. Ch. A. Kane, L'aventure ambiguë, p. 60. 
from. These interpreters held a position of considerable influence and power during conquest and occupation and were highly respected and sometimes feared by the local population, amply illustrated in historical novels such as Kourouma's Monnè (1990) and, again, Hampâté Bâ's Wangrin.

By the late 1800s, the French colonizers had institutionalized an educative system specifically geared towards the formation of African auxiliaries :

[...] [D]ès cette époque, les grandes orientations données à l'enseignement visaient à donner aux Africains un enseignement à but utilitaire [...]. L’enseignement sera développé aux colonies dans la mesure où il servira les intérêts coloniaux ${ }^{15}$.

The French instructed those, whom they hoped would become their future allies, forming future colonial administrators by giving them a French education - or at the least, an education in French. As future intermediaries between the larger (non French speaking) population and the colonial apparatus, interpreters fulfilled important and influential communicative and interpretive roles, as Kouadio shows:

Ce besoin d'auxiliaires capables de seconder l'autorité coloniale pour réaliser son programme d'expansion politico-économique va guider les responsables de l'enseignement dans leur choix du contenu de celui$\mathrm{Ci}^{16}$.

In fact, interpreters were crucial to the functioning of the colonial administration and a central part of its institutionalization ${ }^{17}$. This we can see in Hampâté Bâ's biographical novel Wangrin. There, he recounts - with humor and also sarcasm - the interpreter Wangrin's rise to wealth, prestige and power (and his eventual fall) during the early 1900s. French administrators were frequently rotated in the colonies, which inhibited their ardor to learn African languages, and which as a consequence gave interpreters indispensable positions ${ }^{18}$. Today,

I5. J. N'G. Kouadio, “Le français en Côte d'Ivoire”, p. 2.

I6. Ibid.

I7. B. N. Lawrance, E. L. Osborne, R. L. Roberts, Intermediaries, interpreters, and clerks, p. 11; R. A. Austin, "Colonialism from the Middle".

I8. E. L. Osborn, " Circle of iron ”, p. 43; M. Klein, "African participation in colonial rule", p. 279. 
many Burkinabe do not speak or understand sufficient French to follow the proceedings in a court hearing. They need to communicate with judges and prosecutors via the court interpreter. Moving in time to the Burkinabe courtroom of today, we can observe, that, contrary to colonial times, when French administrators were not sufficiently well versed in African languages, most judges now understand and speak the language most used in Bobo-Dioulasso, Jula. So we might ask how indispensable the interpreter in fact is now when judges could (but do not) communicate directly with defendants.

The colonial interpreter, the go-betweens, moving adeptly between the French imposed administrative apparatus and African daily reality, enjoyed immense prestige and they were indispensable to the French colonial officials. Nevertheless, interpreters were often treated with disdain, sometimes even publicly ridiculed ${ }^{19}$. This top-down talk can be seen as typical for a highly hierarchized organization or society. The French justice system in use in Burkina Faso is managed in a strictly hierarchical way ${ }^{20}$. Burkinabe social structure as well functions and is organized hierarchically, but not along the same lines as French jurisdiction. In the courtroom in Burkina Faso, these two hierarchical systems come into contact. Wangrin had perfected this profession, profiting equally from both the French administrators and the African people. The subtitle of the book Hampâté Bâ wrote in his emulation, is les roueries d'un interprète africain. Le Quellec Cottier describes precisely these roueries or the cunning of Wangrin and other (literary) figures as an art mastered to perfection ${ }^{21}$. More so, colonial intermediaries' cunning has evolved into more than an art because it allows them to speak in a voice of their own; they have taken back, appropriated, their history by telling their stories in their own words 22 .

Translating between African languages and French was historically only needed between white/European/French administrators and the African population. In this sense allowing court members the sole use of French in the courtroom today is the continuation of a system installed

19. R. Mopoho, "Statut de l'interprète dans l'administration coloniale en Afrique francophone”.

20. R. Ginio, "Negotiating legal authority in French West Africa”.

2I. Ch. Le Quellec Cottier, "Le romanesque africain sous le signe de la ruse”, p. 103.

22. Ibid., p. 114. 
and perpetuated since colonial times. Following Hampâté Bâ, we can describe today's court interpreters in Bobo as "blanc-noirs":

"Blancs-noirs" sont les fonctionnaires et agents indigènes de l'administration, les Européens étant appelés "blancs-blancs"; les Africains sont les "noirs-noirs" 23 .

Today, court interpreters translate between the French speaking court, the judges and prosecutors, and the African languages speaking defendants. If we continue to follow Hampâté Bâ's logic, this makes judges/ prosecutors into "white people", colonizers imposing their way of handling things.

Judges as colonizers? Well, French is the language in which judges have learned the law, it is the language in which justice is spoken. In the courtroom in Burkina Faso today, judges (and prosecutors) use French - exclusively. So the French language is intimately tied to the system of justice while being intelligible only to those participants in the courtroom space who have had an education allowing them access to this language. Only $0,01 \%$ of Burkinabe use French as a family language and "les francophones confirmés du pays constituent moins de $2 \%$ de la population totale" ${ }^{24}$, which means that the vast majority of defendants needs an interpreter in court.

That might as well be so, the Burkinabe judicial system being an exact copy of the French justice system. Imported with conquest, institutionalized during colonialism and carried over into the independent state of Haute Volta, one judge explains that "le droit africain moderne est une copie collée du droit occidental. Il contient des expressions, des concepts, des principes ignorés des africains, donc difficile à traduire en langues africaines. En plus, des juges et ou greffiers d'ethnies différentes ne comprennent pas les mêmes langues africaines [...]" 25. Judges have decided that French alone can be used in a courtroom. The distance thus created between the educated, French speaking members of the court

23. A. Hampâté Bâ, L'étrange destin de Wangrin ou les roueries d'un interprète africain, p. 371, endnotes 108 and 109.

24. I. Diallo, "Les langues nationales, outils de promotion du français au Burkina Faso", p. $13 \mathrm{f}$.

25. Email 12.8.2014. 
and the (often illiterate) defendants works to the advantage of those who speak French.

The French language and justice system have come to stay - they have invited themselves into the Burkinabe courtroom. We are getting closer to answering our initial question of who sent out the invitation. It continues to be a (two) class system, favoring those who master enough French to follow court proceedings without an intermediary, the interpreter. And just like in the early days of colonization, when French citizens were judged differently than Africans, French speakers today are judged differently ${ }^{26}$. First the French colonialists were ignorant of the African languages spoken in their administrative district while today Africans seem to be ignorant of standardized French. As already mentioned, this creates a huge distance between the court and the reality of every day life of Burkinabe society; a much bigger distance than judicial systems transmit with their highly technical vocabulary and modes of expression. In Burkina Faso, this distance is particularly marked through the insistence on using only French and through the imposition of a French model judicial system.

The systematic, continuing marginalization of African languages on all levels of the educative system brought the population to believe African languages are unfit for technical, administrative, judicial, scientific or generally intellectual communication ${ }^{27}$. University students prefer a communication in French to a conversation in an African language, because speaking French makes their utterances more pertinent, they say $^{28}$.

Another consequence of these language attitudes in Burkina Faso today is the fact that, since Jula or any other African language are not supposed to be used in government, administration or education, "there is no need to develop the expressive power of the indigenous language[s] beyond the colloquial level [...]. This affects the vocabulary of the language, the terminology for all specialized fields $[\ldots]$ and $[\ldots]$

26. The French colonizers installed two different justice systems, one for French citizens - both Africans and Europeans - and the other for the African population (see for example R. Ginio, "Negotiating legal authority in French West Africa”). For reasons of space we cannot go into detail here.

27. E. Adegbija, "Language attitudes in West Africa”; L.-J. Calvet, Histoire du français en Afrique, M. Mayrhofer-Deák, Sprache macht Schule.

28. N. Tarr, "Le message choisit la langue". 
the metaphorization processes allowing the exploration of new mental experiences in art, science, religion, etc." ${ }^{29}$. The whole process is thus self-perpetuating.

Reality draws a different picture, however, and the apparent lack of vocabulary is not necessarily an insurmountable obstacle to technical discussions in Jula, as we can observe in today's language practices in the courtroom in Bobo-Dioulasso. The fact that interpreters translate judicial vocabulary and ideas from and into Jula quite eloquently, attests to the expressive power of this language ${ }^{30}$. If, indeed, defendants actually understand is a different question and object of other reflections for another paper. Here, we have seen that the colonial past has been invited into today's Burkinabe courtroom by judges and via the French language.

\section{Wangrin, Tiekoro and Patrick}

There is a considerable amount of historical research discussing the role African clerks played in the installation and administration of colonial rule ${ }^{31}$. They contributed to the colonial project from the middle ${ }^{32}$, facilitating the installation of French hegemony. What we also have are abundant works of faction ${ }^{33}$ such as Amadou Hambâté Bâ's L'étrange destin de Wangrin (1973) or his Mémoires (1991, 1994). Hampâté Bâ has

29. R. Dirven, "The use of languages and language policies in Africa”, p. 180.

30. There are some unpublished glossaries of Jula-French-Jula legal vocabulary available from the authors themselves, from research institutions or the university in Ouagadougou.

3I. R. Mopoho, "Statut de l'interprète dans l'administration coloniale en Afrique francophone”; E. L. Osborn, "Circle of iron””; B. N. Lawrance, E. L. Osborn, R. L. Roberts, Intermediaries, interpreters, and clerks; R. A. Austin, "Colonialism from the Middle".

32. R. A. Austin, "Colonialism from the Middle".

33. The term faction brings together fact and fiction. On the classification of Hampâté Bâ's work L'étrange destin de Wangrin as novel or biography, fiction or non-fiction, see J.-M. Moura, "Textural ownership in L'étrange destin de Wangrin (The Fortunes of Wangrin) by Amadou Hampâté Bâ”. In anthropology the method of transcribing observations or lived experiences long after the actual happening is considered debatable as reliable source of information. That is why I prefer designating the work Wangrin as faction and not as the "autobiography of a dead man", as Moura designates it. 
repeatedly insisted that his book Wangrin was not a work or fiction and that he was only the medium transmitting the life-story of his friend Wangrin who had asked him, Hampâté Bâ, to tell this story after his death ${ }^{34}$. Actually, quite a number of literary works by African authors describe the lives and jobs of men (yes, only men) hired by the colonial administration: Bernard Dadiés autobiographical novel Climbié (1952) or L'odyssée de Mongou by Pierre Samy (1977) describe the lives of men working during and for the French colonial administration, while Le vieux nègre et la médaille by Ferdinand Oyono (1956) describes the workings of the colonial administrative apparatus, to name just these more famous books.

The man working as interpreter at the criminal court, the tribunal de grande instance in Bobo-Dioulasso, lets call him Patrick, has been working at one or the other court in Bobo since 2000. He was born in Bobo in 1973. This makes him the oldest among the five men interpreting during trials in Bobo, both in terms of biological age and in terms of how long he has been working at the court. Patrick went to school in Bobo, but decided to "go look for himself", aller se chercher as he calls it, before getting any kind of high school degree. Patrick wanted to earn money, so he started a small business selling cassettes and CDs, une discothèque, and, well, animal feed. He was doing ok. His sister-in-law who worked at the ministry of justice in Ouagadougou, thought he could do better, however. She decided to get him "off the streets" and into a job she considered decent. So she organized for him to become the personal driver of the president of the appellate court in Bobo-Dioulasso, judge Bah. Patrick enjoyed working for the president very much; in fact, he insists on telling me that he was treated like a son by the president's family, spending time with them also during vacation. Unfortunately, Bah got very ill and passed away, which motivated Patrick's sister-in-law to become active again on his behalf, this time getting him a job as government employee or public servant, as fonctionnaire. Patrick was hired as agent de liaison by the appellate court in 2009.

In 2013 the Burkinabe government decided to put into action the law concerning language use in court, which had been ratified in 1999. But recruiting court interpreters was a challenge since the profession as

34. J.-M. Moura, "Textural ownership in L'étrange destin de Wangrin (The Fortunes of Wangrin) by Amadou Hampâté Bâ”. 
such does not exist - there are no interpreting studies offered in Burkina Faso teaching African languages or court interpretation. So the ministry of justice had to improvise, looking for the best possible alternative to a professional interpreter. Patrick had been working at the court for some years now, he spoke Jula and French, so when the ministry launched the search, his sister-in-law made sure it was him who got the job. He started interpreting during trials at the tribunal de grande instance, while continuing his duties as agent de liaison. Patrick translates from French into Jula for defendants. And because most judges speak Jula, he does not always translate defendants' words into French for them. And this is where Patrick resembles the king's linguist more than he does Wangrin or Tiekoro. The griot-linguist comes close to expectations asked of Patrick today. Ideally, both transmit the king's or the judge's message without adding anything of their own - or omitting anything. And just like the king of old, the judge today understands the language the interpreter is hired to translate into.

So the king's message was transmitted to the people through the censure of his linguist. Later, being able to communicate with the colonized was one of the preconditions for the imposition of colonial power. "This went beyond the (trivial) fact of verbal exchanges, because in the long run such exchanges depended on a shared communicative praxis providing the common ground on which unilateral claims could be imposed" 35. The French occupiers in West Africa soon realized that in order to further their colonial project, they had to be able to reach the local population. For this purpose they needed autochthonous intermediaries who were able to speak, write and read French ${ }^{36}$. These intermediaries were crucial. They had to not only master the French language, but also legal and cultural categories, which they then had to translate in terms that made sense to Europeans and Africans alike ${ }^{37}$. This is nicely illustrated by the words of the character of Pierre-Louis, a retired judge and lawyer, who, soliciting Samba Diallo's attention in L'aventure

35. J. Fabian, Language and colonial power, p. 3.

36. L.-J. Calvet, Histoire du français en Afrique, p. 18. See also J. Riesz, Französisch in Afrika.

37. B. N. Lawrance, E. L. Osborne, R. L. Roberts, Intermediaries, interpreters, and clerks, p. 23. 
ambiguë during an unsatisfying walk through Paris, expresses it such that:

J'ai été magistrat et j'ai servi un peu partout, chez vous, pendant vingt ans. La retraite est venue ensuite, à point nommé. Je commençais à avoir assez des emmerdements du système. Alors, je suis descendu du siège pour aller de l'autre côté du barreau. Douze années durant, j'ai défendu mes compatriotes [...] contre l'État et les colons français. De la merde, ces colons... [... ] Tous les Noirs devraient étudier le droit des Blancs [...] le droit de tous les colonisateurs, ainsi que leurs langues. Vous devriez étudier la langue française... je veux dire, profondément [...] Car, savez-vous: ils sont là, tout entiers, dans leur droit et leur langue. Leur droit, leur langue, constituent la texture même de leur génie, dans ce qu'il a de plus grand et dans ce qu'il a de plus néfaste, aussi ${ }^{38}$.

Today, five decades after Pierre-Louis' statements, defendants in court can only participate in their own trials by way of an interpreter. In order to make defendants "belong" 39 , in order to domesticate them to the courtroom space, defendants need an interpreter. The courtroom space is here understood in the sense that Elijah Anderson (2015) uses the concept of "white space": a place where some people belong and some do not by virtue of certain characteristics. In our case, the characteristic would be the command of a particular language - French.

Is the interpreter purely decorative, then, part of the protocol like the king's djeli, translating the judge's message for defendants without adding a meaning of his own? We can also see him as indispensable like his colonial predecessor, translating for the non-French speaking defendants. Or he is there to underline the judge's position as the courtroom participant holding power over proceedings. Because why, exactly, the judge does not simply communicate directly with defendants, avoiding the detour via the interpreter, can be read to mean he insist upon his royal position in the courtroom. And this protocol needs to be strictly adhered to, as the choreography of courtroom proceedings amply shows.

38. Ch. A. Kane, L'aventure ambiguë, p. 142-144.

39. E. Anderson, "The white space". 


\section{Epilogue in lieu of a conclusion}

The ministry of justice announces the next session of criminal court hearings at the tribunal de grande instance in Bobo-Dioulasso, Burkina Faso, for next Tuesday. The main prosecutor will bring 21 individual cases to trial on this day, including involuntary homicide, theft, and abuse of confidence, among others. The names of defendants (prévenus), victims (partie civile) and witnesses (témoins) are printed together with the crime on the invitation. The file number has its own space as well, figuring prominently. The invitation is written in French, printed out and stuck to the outside of the gate at the tribunal de grande instance for all to see and study. Maintaining asymmetrical conditions is always a question of who has the power to maintain the status quo - and whom these asymmetrical conditions ultimately serve. Judges act like kings or colonizers, deciding that only French can be used in court. Why? It is them, together with their colleagues the prosecutors, who have pursued long-term studies, going to university and the école nationale de l'administration et de la magistrature for another year. Their entire education was in French. The law is spoken in French, too, as we have seen. A look at courtroom life in Senegal - also a French West African country, designating only French as official language in its constitution - surprises us with the fact that judges speak Wolof, the language with the most speakers in Senegal. Judges thus communicate directly with defendants, avoiding the detour via an interpreter. This confirms my hypothesis that it is indeed judges in Burkina Faso who interpret article 35 of the constitution to mean that they can use only French in the courtroom; all other languages need interpretation into French. We might thus say that it is judges who send out invitations, allowing the colonial past entry into the courtroom of today. The colonial present is everyday reality in the Burkinabe courtroom ${ }^{40}$.

Natalie TARR

Center for African Studies

University of Basel

40. D. Gregory, The colonial present. 


\section{BIBLIOGRAPHY}

Adegbija, Efurosibina, "Language attitudes in West Africa", International J. Soc. Lang, 141 (2000), p. 75-100.

Anderson, Elijah, "The white space: race, space, integration, and inclusion?", Sociology of race and ethnicity, 1/1 (2015), p. 10-21.

Austin, Ralph A., "Colonialism from the Middle. African clerks as historical actors and discursive subjects", History in Africa, 38 (2011), p. 21-33.

Bandia, Paul, "Esquisse d'une histoire de la traduction en Afrique", Meta, 503 (2005), p. 957-971.

Callon, Michel, "Some elements of a sociology of translation: domestication of the scallops and the fishermen of St Brieuc Bay", in Power, action and belief: a new sociology of knowledge?, ed. by J. Law, London, Routledge, 1986, p. 196-223.

Calvet, Louis-Jean, Histoire du français en Afrique: une langue en copropriété?, Paris, Éditions Écriture, 2010.

Canut, Cécile, Le spectre identitaire: entre langue et pouvoir au Mali, Limoges, Lambert-Lucas, 2008.

Dadié, Bernard, Climbié, Paris, Seghers, 1952.

Davies, Bronwyn, Harré, Rom, "Positioning: the discursive production of selves", Journal for the Theory of Social Behavior, 20/1 (1990), p. 43-63.

Diallo, Issa, "Les langues nationales, outils de promotion du français au Burkina Faso", in Colloque développement durable, leçons et perspectives: actes, Ouagadougou, Burkina Faso, du $1^{\mathrm{er}}$ au 4 juin 2004, colloque organisé par l'Agence universitaire de la Francophonie et l'Université de Ouagadougou dans le cadre des manifestations du $10^{\text {e }}$ Sommet de la francophonie, 2007, p. 13-16.

Dirven, René, "The use of languages and language policies in Africa: goals of the LiCCA program", International J. Soc. Lang, 100/101 (1993), p. 179-189. 
FABIAN, Johannes, Language and colonial power: the appropriation of Swahili in the former Belgian Congo 1880-1938, Cambridge, Cambridge University Press, 1986.

Ginio, Ruth, "Negotiating legal authority in French West Africa: the colonial administration and African assessors, 1903-1918", in Intermediaries, interpreters, and clerks: African employees in the making of colonial Africa, ed. by Benjamin N. Lawrance, Emily Lynn Osborn, Richard L. Roberts, Madison, University of Wisconsin Press, 2006, p. 115-138.

Gregory, Derek, The colonial present, Maiden/Oxford, Blackwell Publishing, 2004.

Hampâté BÂ, Amadou, L'étrange destin de Wangrin ou les roueries d'un interprète africain, Paris, Éditions 10/18, 1973.

—, Amkoullel, l'enfant peul (Mémoires), Actes Sud, 1991.

—, Oui, mon Commandant! (Mémoires II), Actes Sud, 1994.

Kane, Cheikh Amidou, L'aventure ambiguë, Paris, Éditions 10/18, 1961.

Klein, Martin, "African participation in colonial rule: the role of clerks, interpreters, and other intermediaries", in Intermediaries, interpreters, and clerks: African employees in the making of colonial Africa, ed. by Benjamin N. Lawrance, Emily Lynn Osborn, Richard L. Roberts, Madison, University of Wisconsin Press, 2006, p. 273-285.

Kouadio, Jérémie N'Guessan, “Le français en Côte d'Ivoire: de l'imposition à l'appropriation décomplexée d'une langue exogène", Documents pour l'histoire du français langue étrangère ou seconde, 40/41 (2008), en ligne: <http://dhfles.revues.org/125>.

Kourouma, Ahmadou, Monnè, outrages et défis, Paris, Seuil, 1990.

Lawrance, Benjamin N., Osborn, Emily Lynn, Roberts, Richard L., Intermediaries, interpreters, and clerks: African employees in the making of colonial Africa, Madison, University of Wisconsin Press, 2006.

Le Quellec Cottier, Christine, "Le romanesque africain sous le signe de la ruse: L'étrange destin de Wangrin d'Hampaté Bâ et Monnè, outrages et défis d'Ahmadou Kourouma", Études de Lettres, 1 (2008), p. 103-118.

Mayrhofer-Deák, Marietta, Sprache macht Schule: Neokoloniale Erfahrungen in Burkina Faso, Saarbrücken, VDM Verlag, 2009. 
-, Der imperiale Mensch: die moderne und koloniale Erziehung in Französisch-Westafrika aus soziologischer Perspektive, Unveröffentlichte Dissertation, Universität Wien, 2014.

Midionouan, Guy Ossito, "Portée idéologique et fondements politiques de la francophonie (vue d'Afrique)", Peuples Noirs, Peuples Africains, 59-62 (1988), p. 63-84.

Miккelsen, Holly, Jourdenais, Renée, The Routledge handbook of interpreting, London/New York, Routledge, 2015.

Мороно, Raymond, "Statut de l'interprète dans l'administration coloniale en Afrique francophone", Meta: journal des traducteurs / Meta: Translators' Journal, 46/3 (2001), p. 615-626.

Moura, Jean-Marc, "Textural ownership in L'étrange destin de Wangrin (The Fortunes of Wangrin) by Amadou Hampâté Bâ", Research in African Literatures, 37/1 (2006), p. 91-99.

Osborn, Emily Lynn, "'Circle of iron': African colonial employees and the interpretation of colonial rule in French West Africa", The Journal of African History, 44/1 (2003), p. 29-50.

Oyono, Ferdinand, Le vieux nègre et la médaille, Paris, Éditions 10/18, 1956.

Riesz, János, Französisch in Afrika: Herrschaft durch Sprache, IKO Verlag für Interkulturelle Kommunikation, Frankfurt, 1998.

Samy, Pierre, L'odyssée de Mongou, Paris, Hatier, 1977.

TARR, Natalie, "Le message choisit la langue": language choices and attitudes among university students in Bobo-Dioulasso, Burkina Faso, Unpublished MA thesis, University of Basel, 2015. 